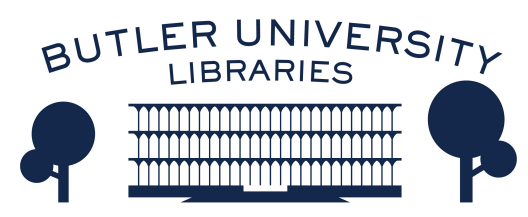

Journal of Hindu-Christian Studies

Volume 13

Article 10

January 2000

\title{
Viewpoint: Christian-Hindu Prayer in Interreligoius Dialogue
}

Anand Nayak

Follow this and additional works at: https://digitalcommons.butler.edu/jhcs

Part of the Religion Commons

\section{Recommended Citation}

Nayak, Anand (2000) "Viewpoint: Christian-Hindu Prayer in Interreligoius Dialogue," Journal of HinduChristian Studies: Vol. 13, Article 10.

Available at: https://doi.org/10.7825/2164-6279.1230

The Journal of Hindu-Christian Studies is a publication of the Society for Hindu-Christian Studies. The digital version is made available by Digital Commons @ Butler University. For questions about the Journal or the Society, please contact cbauman@butler.edu. For more information about Digital Commons @ Butler University, please contact digitalscholarship@butler.edu. 


\title{
VIEWPOINT
}

\section{Christian-Hindu Prayer in Interreligious Dialogue .}

\author{
Anand Nayak \\ Institute for Missiology and Study of Religions, \\ University of Fribourg, Switzerland
}

\section{THE INTERRELIGIOUS DIALOGUE} encounters have always given an important place to common prayer in their programs. Prayer-meetings are organized to celebrate feasts and other significant events in life. The Christian ashrams too have made interreligious prayer the heart of their monastic life. Several prayer-books have now appeared, with prayers collected from different religions, for interreligious prayer meetings. The splendid picture of Pope John-Paul II praying with the Dalai Lama and with other representatives of religions at the Assisi Meeting of 1986 has become a classical symbol of interreligious prayer.

However, the initiative for common prayer in interreligious meetings, as the interreligious dialogue on the whole, has always been a strong Christian initiative to which members of other religions seem to oblige passively, without really taking - or not knowing how to take - an active part. They do not seem to see a meaningful gesture there in praying together with persons of other religions. With Muslims, in fact, there is often an opposition to such an initiative, prayer being the essence of Islam, one of its five pillars, not to be shared with "unbelievers" or with "those who believe imperfectly". Prayer does not seem to fit in a real dialogical context, a domain which calls for a real and spontaneous participation. Where minds and hearts do not meet, there is no real dialogue.

Prayer is a vague concept. It evokes different meanings in different religious contexts. The ambiguity is at its highest in Christianity, where prayer can mean any act done intentionally to lift up the heart towards God. The history of Christian spirituality has in fact brought out different forms of prayer: vocal and mental prayer, the prayer of the heart, to which other forms like praise, meditation, contemplation can be added as forms of prayer. In that way, liturgy and sacraments too are prayer. For a Christian, it is not important how one prays, what method or tradition one makes use of, but that one prays, that is, that one comes in contact with God. Other religions on the contrary seem to have kept up more precise definitions of prayer-forms in their spiritual life. Spiritual activities there do not come under a general concept like "prayer". Terms like dhyana (meditation), stuti (praise), vipassana, satipatthana, dhikr, shukr, salat, and so forth have distinctive meanings linked to particular gestures, postures and forms. One does not get into prayer, like Christians do, off and on in the midst of daily activities without prior corporal and inner preparation. Prayer there is linked to space and time more closely than it could be in Christianity.

Coming more precisely to the subject of Christian-Hindu prayer, the interreligious contacts do not grow on account of barriers of communication. These hurdles are in the structures of the dialogue parties, in the attitude towards prayer adopted in each religion, and in the content of prayer itself. Over the centuries Christianity has 
developed a long and powerful tradition of vocal prayer, the prayer of invocation or imploring, in its community and liturgical prayer. The Christian prays at home and in church uttering vocal prayers to implore God's help, much in the line of "Our Father". The clergy is trained to conduct prayer-services for the community and to pray for the community. In Hinduism however the tradition in this sense is very weak. What is uttered in public is not prayer for needs, but sacred texts, praises (stotra), and mantras. The Hindu may indeed sometimes pray to God for his personal needs; but to implore God in public for the needs of persons or of the community is unknown to him. He or she does not seem to see the need to remind God of what $\mathrm{He}$ should do for others. And their clergy has absolutely no training for dialogue in the way the latter is understood by the Christians. The neo-religious tendencies like that of Ramakrishna or Gandhi, developed under or against Christian influence, does not represent the general Hindu practice of prayer.

In spite of the ambiguities involved, both communities set clear limits for prayer participation. For example, the Hindu yajna and the Christian eucharist are both sacrifices; but in a very different sense of the term. Both of them are "memorials" of sacred institutions on which the very foundations of their religion repose. If the significance given to the sacramental and formal elements vary in the different Christian churches and denominations, the Hindu vedic cult is essentially bound to the rigorous performance (karma) of the ritual in all its visible and invisible forms. Given the highest sacredness of these acts, they do not become objects of interreligious partaking. Neither Christianity nor Hinduism sees an interreligious communion possible in these sacred acts. The Hindu veneration of the idol (puja) on the other hand is more flexible. But the Christian sensibility towards idol worship is so great that an interreligious participation seems to be impossible, at least for the time being.

There is a field where Christianity and
Hinduism come close together: bhakti or "loving participation". On the conceptual level there are deep differences between bhakti and the Christian concept of love. However, God conceived as Person and the personal terms employed to describe the relationship between the human person and the Divine, particularly its psalmodies (bhajans) and praise (stuti) expressed in inter-personal terms, bring it closer to the Christian way of prayer. It should be noted however, that bhakti in Hinduism is only one among many ways of coming in contact with God. Not all Hindus follow this path. In Christianity, however, the personal communication with God belongs to its very core and in that way it appears to be a way of bhakti.

The Hindu meditation (dhyana), too can be a meaningful meeting point. The deep silence and intense awareness implied there are familiar to the Christian. One of the important attempts in this line towards a Christian-Hindu meditation can be seen in Father Anthony De Mello's (1931-1987) Sadhana, a Way to God. This and numerous other books written by or attributed to this Indian Jesuit priest are now available in bookshops all over. The simple but powerful spirituality of De Mello's teachings, taught through refreshing talks and spicy stories, seem to capture the heart and mind of hundreds of persons in India and abroad. I think a meaningful interreligious prayer, in which both Hindus and Christians can pray together, can take place with this method of sadhana which in De Mello's attempt remains within the Christian fold and therefore needs to be reworked for interreligious prayer.

According to De Mello, religion and spirituality lose interest when they become activities of mind, in which the body is given no role to play. Can spirituality be a passionate adventure of both body and soul? Can our breath, feelings, and passions contribute to discover the depths of the Spirit? Can our body too be a pathway to God? The ancient Hindu, Buddhist, and Daoist spiritual teachings, among others, were convinced of the active role that the 
body can play in the awakening of the spirit. Yoga can be a fine example of it. Working on body and breath, yoga leads the aspirant through meditation to the realms of the Spirit. De Mello was a renowned spiritual master in the line of the Spiritual Exercises of St Ignatius of Loyola. In his later life he came in contact with the Hindu and Buddhist spiritual masters whose teaching gave him an impetus to re-trace the sources of the Spiritual Exercises: methods for the awakening of the Heart. His Sadhna, a Way to God is his first attempt to make prayer joyful for his own Jesuit brethren. He wrote in 1978:

I have spent my past fifteen years of my life as retreat master and spiritual director helping people to pray. I hear dozens of people complain that they do not know how to pray; that, in spite of all their efforts, they seem to make no progress in prayer; that they find prayer dull and frustrating. I hear many spiritual directors confess helplessness when it comes to teaching people how to pray or, to put it more exactly, how to get satisfaction and fulfilment from prayer ... Most priests and religious equate prayer with thinking. That is their downfall.

The remedy he proposes is the awakening of the heart through awareness. The methods used are all from the Hindu traditions: awareness of breathing, sensations, thoughts; awareness of emotions, feelings; awareness of imaginations and fantasies :

As long as your mind machine keeps churning out an endless stream of mental verbiage, your mystical mind or Heart will remain dormant. See how sharp a blind person's hearing is. He has lost his faculty of seeing, so he has been forced to sharpen his hearing.
Something similar happens in the mystical world. If we could go mentally blind, so to speak, if we could put a bandage over our mind while we are communicating with God, we might be forced to develop some other faculty for communicating with him - the faculty which, according to a number of mystics, is already straining to move out to him even though it is blocked by the noise within us. the Heart. ${ }^{2}$

However, the Christian can be a little apprehensive of this sadhana over the act of fixing attention on a point (dharana), in awareness, which is the essence of meditation and which causes in the meditator mystical feelings of joy, love, and satisfaction. That has already been remarked by the Catholic Church authorities. Cardinal Ratzinger twice brought out strong admonitions against Roman Catholics using such methods. The second of these warnings was directed against Father De Mello. However, these admonitions have produced no serious action in the Catholic Church for the reason that Father De Mello is read and appreciated more outside than within the Catholic Church. Secondly, the age-old discovery of the Hindu sages in the Upanishads, the discovery of the Heart (atman) is not really a stranger to the Christian spirituality and needs to be revived and brought back to its present-day practice. The awakening of the heart through silence and silent awareness can be a solid ground where Hinduism and Christianity can meet.

\section{Notes}

1. Sadhana, $A$ Way to God, 1985, p. 3.

2. Sadhana p. 26. 